\title{
Investigation of the Relationship between Body Mass Index and Physical Fitness in Older Women*
}

\author{
Mehmet Şirin GÜLER ${ }^{1}$, Selami YÜKSEK ${ }^{2}$, Ömercan GÖKSU ${ }^{3}$ \\ ${ }^{1}$ Kafkas University, Sarıkamış Academy of Physical Education and Sports, Kars, TURKEY \\ ${ }^{2}$ Trabzon University, Faculty of Sport Sciences, Trabzon, TURKEY \\ ${ }^{3}$ Istanbul University, Faculty of Sport Sciences, Istanbul, TURKEY
}

Email:

Type: Research Article (Received: 04.03.2020 - Corrected: ----

- Accepted: 24.03.2020)

\begin{abstract}
This study aimed to examine the effect of Body Mass Index (BMI) on physical fitness levels in women between the ages of 65-75.

The research was conducted with the participation of 687 women who were able to maintain daily life activities independently, who had no serious health problems, and who could be considered healthy in their age category. The cases included in the study were divided into 3 groups as Normal (117 cases), Overweight (273 cases), and Obese (297 cases) according to the calculated Body Mass Index values. Accordingly, those with a body mass index of less than $18.50 \mathrm{~kg} / \mathrm{m} 2$ were classified as Thin, those between 18.50 and $24.99 \mathrm{~kg} / \mathrm{m} 2$ as Normal, those between 25.00 and $29.99 \mathrm{~kg} / \mathrm{m} 2$ as Overweight and those higher than $30 \mathrm{~kg} / \mathrm{m} 2$ as Obese. 687 cases were included in the study, and the categories were designed as Normal, Overweight and Obese since there were no cases below $18.50 \mathrm{~kg} / \mathrm{m} 2$ within the body mass index values calculated among these cases.

In the study, the Senior Fitness Test (SFT) protocol consisting of six stations designed by Rikli and Jones (2001) was used to determine the physical fitness levels of the elderly.

In the analysis of the data obtained from the measurements, arithmetic averages, standard deviations, and differences between the averages were found using SPSS 11.0 for Windows package software. As a result of the Kolmogorov Smirnov test conducted to find the level of distribution of the data, it was determined that all groups presented a normal distribution. One-way ANOVA-Scheffe test was applied to compare the test scores of the cases according to body mass index values. The correlation of the body weight of the groups classified according to body mass index with the test scores was examined at the level of 0.05 and 0.01 .

As a result, among the cases that were grouped according to their body mass index values, the cases with normal BMI values were found to have the best physical fitness test scores. Performance differences between groups were found to be statistically significant according to their BMI values. Especially in obese individuals, it was determined that their movement skills decreased due to weight gain.
\end{abstract}

Keywords: Body Mass Index, Physical Fitness, Elderly

"Presented at the 3rd Academic Sports Research Congress held in Batumi on 09.10.2019 and prepared for publication. 


\section{Introduction}

Aging is a physiological process that occurs in every living being and causes a decrease in all functions. It is also described as all the irreversible structural and functional changes that occur at the level of molecules, cells, tissues, organs, and systems. General signs of aging include decrease in various functions and capacities of the body, decreased adaptation to changes in the internal and external environment, and decreased resistance to potentially harmful effects on the body. Changes in the cell structure, cell number and regeneration ability of the body are observed with aging. The World Health Organization (WHO) considers 60 years of age as the beginning of old age. Many developed countries, on the other hand, refer to the age of 65, especially in terms of the beginning of old age to benefit from the social security system. It is observed that the world population is rapidly aging with a decrease in birth rate and an increase in life expectancy. The population of individuals over the age of 60 is approaching 900 million in the world. According to WHO, countries with the ratio of individuals aged 65 and above to the total population below $4 \%$ are considered to have a young population, 4 to $6.9 \%$ are considered to have a mature population, 7 to $10 \%$ are considered to have and old population, and above $10 \%$ are considered to have a very old population. (Who, 2002).

With aging, there are changes in many physical and physiological parameters, including body composition(Evans, 1995). Obesity, when added to the aging process which can affect a large part of the organism, can affect the life much more negatively. Considering the proportion of the elderly population in the world, studies that can positively affect the welfare level of the elderly gain significance.

In general, it is recognized that the decrease in daily physical activity contributes to the increase in obesity worldwide. (French et al., 1994; Grundy et al., 1999; Williamson et al., 1993). Problems such as sarcopenia that occur with old age cause a decrease in movement and its scope (Lauretani et al., 2003). The loss in physiological capacities due to old age supports the occurrence of obesity with physical losses.

Today, obesity is seen as a major public health problem. The percentage of obese elderly people is increasing worldwide due to the increase in the elderly population and obesity. When obesity in the elderly was examined by gender, it was observed that women were more likely to be obese than men. While the rate of obese older men was $17.7 \%$, the rate of obese older women was $32.8 \%$ in 2014. (Turkish S.I.2018).Physiological changes that occur with aging are accompanied by changes in body composition. The lean body mass, mostly composed of skeletal muscles, decreases by $40 \%$ between the ages of 20 and 70 . Due to this decrease, the resting metabolic rate also decreases. The decrease in physical activity levels at an advanced age, with a decrease in resting metabolism, causes a decrease in total energy expenditure leading to a positive energy balance. (Villareal et. al.,2005)

Physical fitness measurement is widely used in preventive and rehabilitative exercise programs to improve health. In recent years, descriptive, preventive, enhancing and protective practices and studies for the evaluation and development of components affecting health in children, adults and the elderly have gained momentum. Studies show that exercise in the old age contributes to individuals physically and physiologically (Yüksek, 2017; Göksu, Yüksek, Ayan, \& Güler, 2019). In this sense, the study aims to reveal the effects of physical fitness on obesity by examining the relationship between physical fitness level and body weight. 


\section{Material and Method}

The study was conducted with the voluntary participation of 687 women, aged 60-75, who could maintain their daily life activities independently, without serious health problems. Participants of the study were asked for some demographic information, orthopedic or mental disability that may hinder or limit the application of the Test protocol, and those with a neurological or advanced cardiovascular chronic disease were excluded from the study. The participants were asked to take off the clothes such as jackets and coats that could prevent or restrict their movement during the tests. An experienced assistant is assigned to each station to ensure that stations run smoothly. Participants who failed to complete any of the stations containing the test protocol were excluded from the evaluation.

An armless, straight-backed chair with a seating height of $43.18 \mathrm{~cm}$, a custom-made dumbbell weighing $2.27 \mathrm{~kg}$, the distance of 2.44 meters, a funnel, a $50 \mathrm{~cm}$ long wooden ruler, a $1.5 \times 1.5$ $\mathrm{m}$ mat for the step test, a stopwatch, scales, and a tensiometer were used in the study (Rikli , Jones, 2001). Each participant completed the two-minute step test with bare feet on a $1.5 \times 1.5$ mat. The same devices were used for the physical and physiological measurements of all the participants.

A total of 687 participants that met the test criteria and completed the tests were classified, taking into account the body mass index (BMI) norm values determined by WHO, as Thin (0 case) for those with a body mass index less than $18.50 \mathrm{~kg} / \mathrm{m}^{2}$, normal (117 cases) for those with a body mass index between $18.50-24.99 \mathrm{~kg} / \mathrm{m}^{2}$, Overweight ( 273 cases) for those with a body mass index between 25.00 and $29.99 \mathrm{~kg} / \mathrm{m}^{2}$, and Obese (297 cases) for those with a body mass index greater than $30 \mathrm{~kg} / \mathrm{m}^{2}$. The categories were designed as Normal, Overweight and Obese since there were no cases in the Thin (under $18.50 \mathrm{~kg} / \mathrm{m}^{2}$ ) category within the body mass index values calculated in the study.

The body mass index (BMI) of the participants was calculated by dividing the body weight by the square of the height in meters and recorded in $\mathrm{kg} / \mathrm{m}^{2}$.

\section{Tests Applied}

The Senior Fitness Test (SFT) protocol consisting of six-stations and developed by Rikli and Jones to determine the physical fitness levels of the elderly aged 60-94, was used in the study (Rikli \& Jones, 2001)

Before the tests were applied to the participants, each station of the test protocol was explained and demonstrated one by one, and they were subjected to a warm-up (walking, jogging, stretching exercises) period of 4-5 minutes. The test protocol consisted of 30-sec Chair Stand (30CST), Arm Curl Test (ARCLT), 2-min Step (2MST), 8 Foot Up-and-Go (8FUAGT), Chair Sit \& Reach (CSRT), Back Scratch (BST) test stations.

\section{Statistical Analysis}

In the analysis of the data obtained from the measurements, arithmetic averages, standard deviations and differences between the averages were found using SPSS 11.0 for Windows package software. As a result of the Kolmogorov Smirnov test conducted to find the level of distribution of the data, it was determined that all the groups presented a normal distribution. The comparison of the test scores of the cases according to their body mass index values was made with the One-Way ANOVA-Scheffe test. The correlation with test scores according to body mass index was examined at the level of 0.05 and 0.01 . 


\section{Findings}

Table 1. Some Descriptive Statistics of Cases Participating in the Research

\begin{tabular}{|c|c|c|c|}
\hline Variables & & $\mathrm{n}$ & $\%$ \\
\hline \multirow{6}{*}{$\begin{array}{l}\text { Educational } \\
\text { Background }\end{array}$} & None & 330 & 48.0 \\
\hline & Literate & 78 & 11.4 \\
\hline & Primary School & 236 & 34.4 \\
\hline & Secondary School & 16 & 2.3 \\
\hline & High School & 17 & 2.5 \\
\hline & University & 10 & 1.5 \\
\hline \multirow{4}{*}{ Income Level } & Low & 60 & 8.7 \\
\hline & Middle & 441 & 64.2 \\
\hline & High & 163 & 23.7 \\
\hline & Very High & 23 & 3.3 \\
\hline \multirow{8}{*}{ Profession } & Civil Servant & 19 & 2.8 \\
\hline & Worker & 10 & 1.5 \\
\hline & Teacher & 10 & 1.5 \\
\hline & Farmer & 2 & 0.3 \\
\hline & Housewife & 638 & 92.9 \\
\hline & Doctor/Nurse & 2 & 0.3 \\
\hline & $\begin{array}{c}\text { Self- } \\
\text { Employed/Tradesw } \\
\text { oman } \\
\end{array}$ & 5 & 0.7 \\
\hline & Other & 1 & 0.1 \\
\hline
\end{tabular}

Table 2. Age, Height, BMI and body weight values of the groups formed according to the BMI values of the cases participating in the research

\begin{tabular}{rccccc}
\hline Parameters & Category & Min & Max & X & Sd. \\
\hline \multirow{2}{*}{ Age Years-old } & Normal & 60.00 & 75.00 & 67.27 & 4.83 \\
\cline { 2 - 6 } & Overweight & 60.00 & 75.00 & 66.61 & 4.60 \\
\hline
\end{tabular}




\begin{tabular}{|c|c|c|c|c|c|}
\hline $\begin{array}{l}1 \times \times 7 \\
\text { IntJSCS }\end{array}$ & \multicolumn{4}{|c|}{ International Journal of Sport Culture and Science (IntJSCS) } & \multirow{2}{*}{$\begin{array}{c}\text { March } 2020 \\
4.59\end{array}$} \\
\hline & Obese & 60.00 & 75.00 & 66.20 & \\
\hline \multirow{3}{*}{ Height $\mathrm{Cm}$} & Normal & 140.00 & 178.00 & 157.74 & 7.81 \\
\hline & Overweight & 140.00 & 176.00 & 156.27 & 6.56 \\
\hline & Obese & 138.00 & 171.00 & 155.31 & 6.24 \\
\hline \multirow{3}{*}{$\mathrm{BMI} \mathrm{Kg} / \mathrm{M}^{2}$} & Normal & 18.59 & 24.99 & 23.03 & 1.49 \\
\hline & Overweight & 25.00 & 29.97 & 27.55 & 1.41 \\
\hline & Obese & 30.00 & 45.78 & 33.57 & 3.18 \\
\hline \multirow{3}{*}{ Body Weight Kg } & Normal & 42.00 & 80.00 & 57.50 & 6.82 \\
\hline & Overweight & 55.00 & 98.00 & 67.19 & 6.57 \\
\hline & Obese & 62.00 & 120.00 & 81.10 & 10.15 \\
\hline
\end{tabular}

In the evaluation, the minimum, maximum, average and standard deviation scores of the age, BMI, height, and body weight values of the participants were examined according to normal, overweight and obese variables (Table 2).

Table 3. Some variables belonging to the groups formed according to the BMI values of the participants in the research, statistical data of the test scores and the differences between the groups

\begin{tabular}{|c|c|c|c|c|c|c|c|}
\hline Parameters & Category & Min & Max & $X$ & $\mathrm{Sd}$. & $\mathrm{p}$ & $\begin{array}{l}\text { Difference } \\
\mathrm{S}\end{array}$ \\
\hline \multirow{3}{*}{$\begin{array}{l}30 \text { CST } \\
\text { Chair Stand Test } \\
\text { (times/30sec) }\end{array}$} & Normal & 7.00 & 20.00 & 14.21 & 2.91 & \multirow{3}{*}{0.000} & \multirow{3}{*}{$\begin{array}{l}\mathrm{N}-\mathrm{W}^{* *} \\
\mathrm{~N}-\mathrm{O}^{* * *}\end{array}$} \\
\hline & $\begin{array}{l}\text { Overweig } \\
\text { ht }\end{array}$ & 7.00 & 21.00 & 13.01 & 2.93 & & \\
\hline & Obese & 6.00 & 22.00 & 12.65 & 2.94 & & \\
\hline \multirow{3}{*}{$\begin{array}{l}\text { ARCLT } \\
\text { Arm Curl Test } \\
\text { (times/30sec) }\end{array}$} & Normal & 9.00 & 21.00 & 14.56 & 3.24 & \multirow{3}{*}{0.224} & \\
\hline & $\begin{array}{l}\text { Overweig } \\
\text { ht }\end{array}$ & 6.00 & 22.00 & 14.87 & 2.92 & & - \\
\hline & Obese & 5.00 & 23.00 & 15.13 & 3.26 & & \\
\hline \multirow{3}{*}{$\begin{array}{l}\text { 2MST } \\
\text { 2-Min Step Test } \\
\text { steps/2min) }\end{array}$} & $\underline{\text { Normal }}$ & 30.00 & 118.00 & 65.63 & 16.27 & \multirow{3}{*}{0.000} & \multirow{3}{*}{$\begin{array}{l}\mathrm{N}-\mathrm{W}^{*} \\
\mathrm{~N}-\mathrm{O}^{* *} \\
\mathrm{~W}-\mathrm{O}^{* *}\end{array}$} \\
\hline & $\begin{array}{l}\text { Overweig } \\
\mathrm{ht}\end{array}$ & 29.00 & 109.00 & 60.10 & 15.40 & & \\
\hline & Obese & 21.00 & 106.00 & 55.80 & 14.42 & & \\
\hline CSRT & Normal & -19.00 & 22.50 & 1.24 & 7.31 & 0.636 & - \\
\hline
\end{tabular}




\begin{tabular}{|c|c|c|c|c|c|c|c|}
\hline \multirow[t]{2}{*}{$\begin{array}{l}\text { Chair Sit and Reach } \\
\text { Test }(\mathrm{cm})\end{array}$} & $\begin{array}{l}\text { Overweig } \\
\text { ht }\end{array}$ & -20.00 & 17.00 & 0.81 & 6.62 & & \\
\hline & Obese & -18.50 & 22.00 & 1.33 & 6.78 & & \\
\hline \multirow{3}{*}{$\begin{array}{l}\text { BST } \\
\text { Back Scratch Test } \\
(\mathrm{cm})\end{array}$} & Normal & -28.00 & 14.00 & -8.05 & 8.06 & \multirow{3}{*}{0.000} & \multirow{3}{*}{$\begin{array}{l}\mathrm{N}-\mathrm{O}^{* *} \\
\mathrm{~W}-\mathrm{O}^{* *}\end{array}$} \\
\hline & $\begin{array}{l}\text { Overweig } \\
\text { ht }\end{array}$ & -32.00 & 9.50 & -8.27 & 8.18 & & \\
\hline & Obese & -32.00 & 8.50 & -11.74 & 8.09 & & \\
\hline \multirow{3}{*}{$\begin{array}{l}\text { 8FUAGT } \\
\text { 8-Feet Up and Go Test } \\
\text { (sec) }\end{array}$} & Normal & 3.87 & 9.51 & 5.46 & 1.02 & \multirow{3}{*}{0.000} & \multirow{3}{*}{$\begin{array}{l}\mathrm{N}-\mathrm{O}^{* *} \\
\mathrm{~N}-\mathrm{W}^{* *} \\
\mathrm{~W}-\mathrm{O}^{* *}\end{array}$} \\
\hline & $\begin{array}{l}\text { Overweig } \\
\text { ht }\end{array}$ & 3.89 & 12.50 & 6.18 & 1.57 & & \\
\hline & Obese & 4.04 & 15.24 & 6.80 & 1.78 & & \\
\hline
\end{tabular}

N: Normal Group, W: Overweight Group, O: Obese Group, X: Average, SD: Standard Deviation, p: Significance Level of Differences between Groups, ${ }^{* *} \mathrm{p}<0.01,{ }^{*} \mathrm{p} 0.05$.

In the evaluation, the differences between the minimum, maximum, average and standard deviation values of the SFT parameters and the BMI groups were determined according to the BMI categories of the participants in the study (Table 3).

Table 4. The Relationship between BMI and Test Performance

\begin{tabular}{|c|c|c|c|c|c|c|c|}
\hline & \multirow[b]{2}{*}{$\begin{array}{c}30 \text { CST } \\
\text { Chair Stand } \\
\text { Test } \\
\text { (times/30sec) }\end{array}$} & \multirow[b]{2}{*}{$\begin{array}{c}\text { ARCLT } \\
\text { Arm Curl } \\
\text { Test } \\
\text { (times/30sec) }\end{array}$} & \multirow[b]{2}{*}{$\begin{array}{c}\text { 2MST } \\
\text { 2-Min Step } \\
\text { Test } \\
\text { steps/2min) }\end{array}$} & \multirow[b]{2}{*}{$\begin{array}{c}\text { CSRT } \\
\text { Chair Sit and } \\
\text { Reach Test } \\
\text { (cm) }\end{array}$} & \multirow{2}{*}{$\begin{array}{c}\text { BST } \\
\text { Back } \\
\text { Scratch } \\
\text { Test } \\
(\mathrm{cm}) \\
\end{array}$} & \multirow[b]{2}{*}{$\begin{array}{c}\text { 8FUAGT } \\
\text { 8-Feet Up } \\
\text { and Go (sec) }\end{array}$} \\
\hline & & & & & & & \\
\hline \multirow{3}{*}{$\begin{array}{c}\text { BMI } \\
\mathrm{kg} / \mathrm{m}^{2}\end{array}$} & $\mathrm{r}$ & $-0.224^{* * *}$ & 0.063 & $-0.259^{* *}$ & -0.042 & $-0.209^{* * *}$ & $0.342^{* * *}$ \\
\hline & $\mathrm{p}$ & 0.000 & 0.097 & 0.000 & 0.274 & 0.000 & 0.000 \\
\hline & $\mathrm{n}$ & 687 & 687 & 687 & 687 & 687 & 687 \\
\hline
\end{tabular}

In the evaluation, the relationships between the BMI values of the participants and the SFT protocol were determined (Table 4). 


\section{Discussion and Conclusion}

As a result of the statistical evaluation of 687 cases participating in the study, it was determined that, in terms of profession, a vast majority (48\%) were illiterate, $64 \%$ had moderate income levels, and $92.9 \%$ were housewives (Table 1). In addition, the age, height, body weight and BMI values of all the participants of the research were examined according to normal, overweight and obese categories (Table 2).

As a result of the statistical evaluation, when 30 CST, 2 MST, BST, and 8 FUAGT scores were examined, the difference between the group with Normal BMI values and the overweight and obese groups was found to be significant in favor of the Normal BMI group. In addition, the difference between the 2 MST and CST scores between the overweight and obese groups was found to be significant in favor of the overweight group ( $p<0.01)$ (Table 3 ). There was no statistically significant difference between the groups in ARCLT and CSRT scores $(\mathrm{p}>0.05)$. The results of the analysis show that the cases in the Normal BMI group had the highest physical performance, and those in the obese BMI group had the lowest physical performance level.

When the literature is examined, it is seen that the elderly have similar BMI values. Valentine et al. reported an average BMI of $28.35 \mathrm{~kg} / \mathrm{m} 2$ in a field study in which they evaluated the relationship between BMI and physical function in 134 elderly people (Valentine et al.2009). In another study, Syddall et al. evaluated 3225 elderly people and stated the average BMI value as $27.35 \mathrm{~kg} / \mathrm{m} 2$. (Syddall et al., 2019).

In addition, when the relations between the physical fitness tests that constituted the BMI and SFT protocol were examined, a significant negative relationship was determined between the BMI and 30 CST, 2 MST, and BST scores, and a positive relationship with 8 FUAGT scores. It can be stated that leg strength, cardiovascular endurance and upper limb flexibility skills decrease with increasing body weight and body mass index. There was no significant relationship between body weight and arm strength and lower extremity flexibility values ( $>>0.05)$ (Table 4).

Asp et al. (2017), in their study with 2558 participants aged 65 and above, reported that $13 \%$ of physically active individuals faced obesity while this rate was $22 \%$ in physically inactive individuals. In addition, studies indicate that obesity negatively affects physical movement as well as causing various health problems and individuals should be physically active to avoid obesity(Lang, Llewellyn, Alexander, \& Melzer, 2008.Riebe et al., 2009) Villareal et al. (2011) reported, as a result of their study with 107 obese participants over 65 years of age, that weight loss and exercise should be planned and implemented together in order to provide the best improvement in physical functions. In another study, Brach JS et al. found that women with normal weight were physically more active, and their physical functions and walking speed were higher than overweight and obese women and that overweight and obese women had similar levels of physical activity and physical fitness. (Brach, Storti et al.,2004). Goggin and Morrow stated in their study, in parallel with the literature, that $89 \%$ of Americans who were 60 and older knew that physical activity was beneficial for health, however, 69\% of them did not perform adequate physical activity. (Goggin, Morrow,2001). Past studies also support this study.

In a study conducted in Spain, 3605 cases aged 65 and above were examined, and most of the cases in the obese group ( BMI 30 or above) were reported to have a poor physical function. Besides, similar studies have revealed that a decrease in functional capacity is observed as the BMI of older people increases. Moreover, the decrease in BMI values resulting from the 
decrease in body weight is thought to improve functional mobility. (López et al., 2003). Barbosa et al. , in a cross-sectional study with 1894 individuals aged 60 and above, determined that there was a significant decrease in all physical performance tests with aging, with no gender difference. (Aline et al., 2005).

Chronic diseases arising from obesity increase the risk of functional impairment. In the literature, studies have shown that elderly individuals with low BMIs have a high physical function and that a high BMI value leads to poor mobility and decreased physical function in the elderly (Apovian et al., 2002).The decrease in physical function, on the other hand, leads to an increase in health problems and thus a decrease in the quality of life in the elderly.

As a result, it was determined that the patients who were grouped according to body mass index values had the best scores according to the results of the physical fitness test, and the performance differences between the groups were statistically significant. Especially in individuals with obesity, it was discovered that their mobility skills decreased due to weight gain.

Overweight and obesity are serious problems that limit mobility. Decreasing mobility and increasing body weight greatly complicates the life of the elderly especially with the health problems they bring about. Based on the result of the research and literature, it can be said that exercise creates a therapeutic effect without side effects against overweight, obesity and other problems related to obesity in the elderly. 


\section{REFERENCES}

Aline R. Barbosa AR, SouzaJMP, Lebrão MLL, Laurenti R, Marucci MFN.Functional limitations of Brazilian elderly by age and gender differences: data from SABE Survey.Cad Saude Publica.2005, 21(4):1177-85)

Apovian C. M., Frey C.M., Wood G. C, Rogers J. Z, Still C.D. Body Mass Index and Physical Function in Older Women:Obesity Research, 2002; Vol.10: 740 -747.

Asp, M., Simonsson, B., Larm, P., \& Molarius, A. (2017). Physical mobility, physical activity, and obesity among elderly: findings from a large population-based Swedish survey. Public Health, 147, 84-91. https://doi.org/10.1016/j.puhe.2017.01.032

Brach JS, VanSwearingen JM, FitzGerald SJ, Storti KL ve ark. The relationship among physical activity, obesity, and physical function in community-dwelling older women. Prev Med 2004; 39: 74-80.

Evans, W. J. (1995). What Is Sarcopenia? The Journals of Gerontology Series A: Biological Sciences and Medical Sciences, 50A(Special), 5. https://doi.org/10.1093/gerona/50a.special_issue.5

French, S. A., Jeffery, R. W., Forster, J. L., McGovern, P. G., Kelder, S. H., \& Baxter, J. E. (1994). Predictors of weight change over two years among a population of working adults: the Healthy Worker Project. International Journal of Obesity and Related Metabolic Disorders : Journal of the International Association for the Study of Obesity, 18(3), 145-154.

Goggin NL, Morrow JR. Physical activity behaviors of older adults. Journal of Aging and Physical Activity 2001; 9:58-66.

Göksu, Ö. C., Yüksek, S., Ayan, V., \& Güler, M. Ş. (2019). The Importance of Sport in Aging Process. Journal of Education and Training Studies, 7(9), 22-31. https://doi.org/10.11114/jets.v7i9.4350

Grundy, S. M., Blackburn, G., Higgins, M., Lauer, R., Perri, M. G., \& Ryan, D. (1999). Physical activity in the prevention and treatment of obesity and its comorbidities. Medicine and Science in Sports and Exercise, 31(11 SUPPL.).

Lang, I. A., Llewellyn, D. J., Alexander, K., \& Melzer, D. (2008). Obesity, physical function, and mortality in older adults. Journal of the American Geriatrics Society, 56(8), 1474-1478. https://doi.org/10.1111/j.1532-5415.2008.01813.x

Lauretani, F., Russo, C. R., Bandinelli, S., Bartali, B., Cavazzini, C., Di Iorio, A., ... Ferrucci, L. (2003). Age-associated changes in skeletal muscles and their effect on mobility: An operational diagnosis of sarcopenia. Journal of Applied Physiology, 95(5), 1851-1860. https://doi.org/10.1152/japplphysiol.00246.2003

López-Garcia E, Banegas JR, Gutiérrez-Fisac JL, Pérez-Regadera AG, Gañán LD, RodríguezArtalejo F. Relation between body weight and health-related quality of life among the elderly in Spain. Int J Obes Relat Metab Disord. 2003; 27: 701-9

Rikli, RE., Jones, JC. (2001). Senior fitness test manual. Human Kinetics, Champaing, Illinois.

Riebe, D., Blissmer, B. J., Greaney, M. L., Ewing Garber, C., Lees, F. D., \& Clark, P. G. (2009). The relationship between obesity, physical activity, and physical function in older adults. Journal of Aging and Health, 21(8), 1159-1178. https://doi.org/10.1177/0898264309350076 
Syddall,H.Evandrou M.Cooper C. Sayer AA. Social inequalities in grip strength, physical function, and falls among community dwelling older men and women. J Aging Health. 2009;21(6):913-39.

Valentine RJ, Misic MM, Rosengren KS, Woods JA ve ark. Sex impacts the relation between body composition and physical function in older adults. Menopause. 2009;16(3):518-23.

Villareal, D. T., Chode, S., Parimi, N., Sinacore, D. R., Hilton, T., Armamento-Villareal, R., ... Shah, K. (2011). Weight loss, exercise, or both and physical function in obese older adults. New England Journal of Medicine, 364(13), 1218-1229. https://doi.org/10.1056/NEJMoa1008234

Villareal DT, Apovian CM, Kushner RF, Klein S. Obesity in older adults: technical review and position statement of the American Society for Nutrition and NAASO, The Obesity Society.Obes Res.2005;82:923-934

Williamson, D. F., Madans, J., Anda, R. F., Kleinman, J. C., Kahn, H. S., \& Byers, T. (1993). Recreational physical activity and ten-year weight change in a US national cohort. International Journal of Obesity, 17(5), 279-286.

WHO: Active Ageing: a Policy Framework. Geneva, WHO, 2002

Yüksek, S. (2017). The Effects of Performing Prayer on the Physical Fitness Levels of Men Over 60 Years Old. Journal of Education and Training Studies, 5(11), 56-63. https://doi.org/10.11114/jets.v5i11.2641

$\begin{array}{llll}\text { Türkiye } & \text { İstatistik } & \text { Kurumu.Erişim } & \text { tarihi:17,Ocak }\end{array}$ htpp://www.tuik.gov.tr/basinOdasi/İstatistiklerleYaşl1lar/17.03.2016\%20(3).pdf) 